Original Research

\title{
Predictors of Family Stress in Taking Care of Patients with Schizophrenia
}

\author{
Rizky Fitryasari ${ }^{1}$, Nursalam Nursalam ${ }^{2}$, Ah Yusuf ${ }^{2}$, Rachmat Hargono ${ }^{3}$ and Chong-Mei Chan ${ }^{4}$
}

${ }^{1}$ Doctoral Student, Faculty of Public Health, Universitas Airlangga, Surabaya, Indonesia

2 Faculty of Nursing, Universitas Airlangga, Surabaya, Indonesia

${ }^{3}$ Faculty of Public Health, Universitas Airlangga, Surabaya, Indonesia

${ }^{4}$ Department of Nursing Science, University of Malaya, Kuala Lumpur, Malaysia

\begin{abstract}
Introduction: Taking care of schizophrenia patients is challenging and causes stress for the family involved. The study was conducted to identify the predictors of family stress present when taking care of a patient with schizophrenia. The ABCX Stress Theory of Hill was used as the theoretical framework.
\end{abstract}

Methods: This study used a correlational design. The sample was 137 families who were caring for patients with schizophrenia at the Menur Mental Hospital, Surabaya, Indonesia. The sample was obtained by way of purposive sampling. The data was collected by a questionnaire and analysed by multiple regression to determine the relationship of the family's structure, family knowledge, the burden of care, stigma, social support, the patient's illness duration, the patient's frequency of relapse and the patient's severity level with family stress.

Results: The results showed that the family's stress was predicted by the family's structure $(p=0.029)$, stigma $(p=0.000)$, the burden of care $(p=0.000)$, and the patient's frequency of relapse $(\mathrm{p}=0.005)$. The burden of care was the strongest predictor of family stress (Beta $=0.619)$.

Conclusion: The patient's frequency of relapse and stigma were other kinds of family stressor. The stressors stimulated a negative perception, called the care burden. Limited adequacy of the family structure-function will inhibit the family in using other resources, creating family stress. Nurses may develop an assessment format that consists of the family stress predictors in order to create a nursing care plan specific to reframing the techniques of family stress management.

\section{ARTICLE HISTORY}

Received: Feb 27, 2018

Accepted: June 26, 2018

\section{KEYWORDS}

family stress predictors; family; schizophrenia

\section{CONTACT}

\section{Rizky Fitryasari}

$\triangle$ risqiv@yahoo.com.sg

$\equiv$ Faculty of Public

Health, Universitas

Airlangga, Surabaya,

Indonesia

Cite this as: Fitryasari, R., Nursalam, N., Yusuf, A., Hargono, R., \& Chan, C. (2018). Predictors of Family Stress in Taking Care of Patients with Schizophrenia. Jurnal Ners, 13(1), 72-79. doi:http://dx.doi.org/10.20473/in.v13i1.7762

\section{INTRODUCTION}

Schizophrenia is a chronic mental disorder and is a cause of morbidity. Schizophrenia is a persistent and serious brain disease that results in psychotic behaviour, concrete thinking difficulties, an inability to communicate, abnormal affection and difficulties in solving problems and meeting daily needs (Levine \& Levine, 2009; G. Stuart \& Sundeen, 2012). The prevalence of severe mental illness, including schizophrenia, according to Riskesdas (Kemenkes RI, 2013) is 1.7 per 1000 inhabitants, meaning more than 400,000 people suffer from severe mental disorders in Indonesia. The incidence percentage of schizophrenia in East Java was $0.22 \%$, while in Surabaya, it was was $0.2 \%$. The incidence rate of schizophrenia is difficult to decrease due to the high recurrence rates. Based on a preliminary study at the Menur Soul Hospital of Surabaya conducted February-April 2016, the number of inpatients reached 5,925 patients, where $90 \%$ had schizophrenia. The data showed that $80 \%$ of patients with schizophrenia had been treated in previous psychiatric care or had a relapse (Medical Record RSJ Menur, 2016).

Schizophrenia, not only cause suffering for the patients, but also for the people who are closest to the patient as well. Usually, the family is the most affected by the mental disorder. In the interviews with 10 families of patients during the preliminary study at Menur Hospital, 100\% stated that the family experienced high tension during the treatment of the schizophrenic patients at home. The families feel anxious, sad, depressed and angry when faced with 
uncontrollable patient behavior. The families also complained about being physically exhausted by having to keep up with the patient at all times. Additionally, 4 out of 10 families complained of frequent headaches, hypertension, and gastritis after more than 2 years of treating patients with schizophrenia. The families felt like there was a lack of time to do activities because they must always keep with the patients with schizophrenia every day. The situation experienced by families over a long period of time can cause the family to experience stress and anxiety (Biegel, 1995; Stuart \& Sundeen, 2005). Suhita's (2015) study of 87 family members acting as the main caregiver in East Java's Kediri City stated that $75 \%$ had moderate to severe stress.

With the presence of schizophrenia patients being a stressor in the family system, $67.8 \%$ of them feel pressure (Darwin, Hadisukanto, \& Elvira, 2013). Families, as the main caregiver, are susceptible to psychological problems, fostering family conflict and mutual abuse. $76.7 \%$ of families show negative symptoms, including depression and influencing family behavior when treating patients at home. The family often induces irritation due to their inability to cope with the burden. This is done by blaming the patient and disregarding the patient's condition (Brillianita \& Munawir, 2014; Pharoah, Mari, Rathbone, \& Wong, 2010).

Stress experienced by the family is caused by the high burden of care, including feeling worried about the patient's condition related to their health status, future, financial condition, and the fulfillment of their daily needs. The financial condition of the family experienced problems during the treatment of a 12-month schizophrenia patient, as a result of financing the treatment, the fulfillment of the patient's needs, hospital transportation and accommodation costs (Djatmiko, 2007; Ennis \& Bunting, 2013; Hadryś, Adamowski, \& Kiejna, 2011). The presence of schizophrenia patients makes the family face social stigma. Related to the stigma attached to both the patients and their families, $37.5 \%$ of the families had a negative perception of the illness suffered by the patients with schizophrenia. The families are embarrassed and often excluded from community activities involving all family members. The magnitude of the burden, the strength of the stigma both from the family and society, the lack of support for the family and the fluctuating condition of the patients may cause family stress. There are many obstacles faced by the family when taking care and living together with the schizophrenic patient. The lack of knowledge about schizophrenia, the social stigma and social alienation, the cost of treatment, the decrease of the families' health, anxiety, depression, and other things are a series of social problems encountered in the family with the schizophrenic patient (El Tantawy, Raya, \& Zaki, 2010; Suhita et al., 2015). An insurmountable family stress situation creates an unfavorable environment and causes the schizophrenia patients to relapse. The inability of the family to control the emotions and the existence of a stressful family life causes issues and continuous criticism is a cause of patient relapse (Akbar, 2008; Amaresha \& Venkatasubramanian, 2012; Fadli \& Mitra, 2013).

ABCX Hill's Theory, stated by Rice (1987), is the theory that was used in this research study. The theory explains if the families facing uncomfortable situations represented by the letter A, they will make an adaptation effort by utilising social support and personal strengths of the family which are described as letter B. Letter C explains the family's perception during a stressful event, which includes how the family defines the uncomfortable events in their life. The letter $\mathrm{X}$ represents the degree of crisis experienced by the family as a result of the interactions between letters A, B, and C. Based on this model, families who care for schizophrenic patient have limited resources and have a negative view of the situation. They will experience a crisis or more severe stress than other families who are faced with the same pressing event who are better adapted.

The researcher, as a mental health nurse, tried to combine Hill's theory with the assessment stage of Family-Centered Nursing theory (Friedman, 2003). Family-Centered Nursing is a family theory with a nursing care approach. An important step in this theory is the nurse's ability to conduct a family situation assessment, which includes assessing the family and patient factors. The family factors are the strength of the family structure, their economic capacity and the level of family knowledge about schizophrenia. The patient factors are the frequency of relapse, the duration of illness and the illness severity. Based on Hill's theory, Family-Centered Nursing theory (Friedman, 2003) and some of the studies discussed above, the burden of care, stigma and social support for families has the potential to affect the stress experienced by the involved families. This study aims to analyze the influence of family structure, economic ability, knowledge level, the burden of care, stigma, social support, the frequency of relapse, the duration of the illness and the patient's severity level as the predictors of family stress. The results of the study are expected to contribute to nursing science in determining the stress's predictors on the families who care for patients with schizophrenia.

\section{MATERIALS AND METHODS}

\section{Research Design}

This study used a correlation research design that explained the relationship of the factors causing family stress when treating patients with schizophrenia. The study was conducted from June through to September 2017. The study involved 137 family members as respondents, who were obtained by purposive sampling. The inclusion criteria were the families being the primary caregivers of the patients, the patient being more than 20 years old 
and them living in one house with the patient for at least one year. The patient should have been diagnosed with schizophrenia for at least three years (proven by medical records), and have already experienced at least one recurrence. The dependent variable was family stress, while the independent variables included family structure, knowledge level, care burden, stigma, social support, the patient's duration of illness, the frequency of relapse and severity.

\section{Instruments}

The data was obtained through of a questionnaire. The demographic data was assessed using a single item: age. Economic status was measured using a closed questionnaire with questions about the average family's fixed income in a month. The family's structural variables were adapted from the family assessment questionnaire as according to Friedman (2003). The respondents were asked what is their role was when related to the patient (mother, father, spouse, child or other family member).

Family knowledge about schizophrenia was measured using a questionnaire modified from McCubbin \& Thompson (1991). Ten-item questions assessed the family knowledge related to the definition of illness, the effect on the family and the schizophrenia treatment. Each item was rated on a scale of 1 (strongly disagree) to 5 (strongly agree). The items were summed, with the higher scores indicating higher knowledge.

The burden of care variable instrument was prepared based on the Caregiver Strain Index questionnaire (Thornton \& Travis, 2003) and the concept of burden according to the World Health Organization (2008) modified according to the condition of the family who cared for the schizophrenia patient. The instrument consisted of eight-item statements on subjective and objective burden measured using a Likert-scale ranging from 1 (never) to 5 (always). The stigma instrument was developed based on the stigma's dimension (Goffman, 1963) and the definition of stigma (Link \& Phelan, 2001). The instrument consisted of ten-item statements asking about labelling, stereotyping, separation and discrimination. They were measured on a five-point scale (1: strongly disagree to 5: strongly agree). The social support variable was obtained by way of a modified instrument of the Social Support Index (H. I. McCubbin, Paterson, \& Glynn, 1987). The instrument consisted of ten-item statements focused on emotional, informational, instrumental and award support. Frequency was measured on a five-point scale (1: never to 5: always).

The data from the patients was collected related to their illness history. The patient's duration of illness was explained as the first time that the symptoms of schizophrenia appeared up to the current date, expressed in years. The frequency of relapse referred to the number of recurrences and hospitalisations within a year. The severity of illness was measured using the modified Brief Psychiatry Rating Scale (BPRS) (Overall \& Gorham, 1988) 1988). The questionnaire consisted of 18-item statements filled in by a doctor or nurse in charge, assessing the positive, negative and affective symptoms performed by the patient. Each item was rated on a scale of 1 (no symptoms) to 4 (severe). All items were added together, while ahigher score indicated higher severity symptoms.

The family stress variable was measured using a modified questionnaire using the Symptom Rating Test (Kellner \& Sheffield, 1973). The questionnaire consisted of a ten-item statement on the psychological and physical symptoms felt by the family over the last three months, rated in 5-point of scale ranging from 1 (never) to 5 (always). All items are totalled, with a higher score indicating a higher severity of family stress. All of the instruments had been already tested for validity and reliability, in a pilot study consisting of 25 respondents. Each item in the statements reached validity $(r>0.514)$ and each questionnaire reached reliability as well $(>0.8)$.

\section{Data Analysis}

Descriptive analysis was used for the respondents' characteristic and for the variable description (Table 1 and 2). We used multiple regression analysis to identify the predictors of family stress during the treatment of patients. We created a p-value table between the independent variables and the dependent variable (Table 3). Based on this table, we removed economic status, family knowledge and social support from the regression model because these three independent variables have a $p$-value $<0.25$. Further testing was performed to determine which variables are valid for being a family stress predictor. A regression test was done until all of the variables had a value $<0.05$. Valid variables that can be used as a predictor of family stress are family structure, maintenance burden, stigma and the frequency of relapse. The four variables have been able to prove the existential assumptions (mean: 0.000, SD: 5.824), interdependence assumptions (Durbin Watson: 1.913), linearity assumptions ( $p=0.000)$, homoscedasticity (norms of data spreads along or zero) data (normal distributed data and on PP Residual Plot of data spread around the diagonal line) and the multi-collateral assessment (VIF <10). The four independent variables were used in simultaneous regression analyses. The level of statistical significance was set at $\mathrm{p}<0.05$.

\section{Ethical clearance}

The respondents were families who accompanied patients to the outpatient unit of the Mental Hospital of Menur. The participants were recruited on the basis of ethical principles. The participants involved in the study had previously received a written explanation of the purpose of the research, and the procedures, rights and obligations, benefits and 
disadvantages involved in the study. Only the participants who had been given informed consent were involved in the study. This study was given ethical approval from the Ethical Committee of Menur Mental Hospital, number 423.4 / $72 / 305 / 2017$.

\section{RESULTS}

\section{Characteristics of the respondent}

The characteristics of respondents have been presented in Table 1 . The majority of respondents were between the ages of 46 to 65 years old. A lot of them were the mother of a patient with schizophrenia. The others were made up of their siblings, relatives, children, spouse and father. Almost half of the monthly family income was more than 4.000.000 IDR. Most of the patients had been diagnosed with schizophrenia for more than ten years and almost half of them were experience relapse one to three times each year.

\section{Variables description}

The variables' description has been explained in Table 2. The average of family knowledge was 37.93 $(\mathrm{SD}=3.843)$. The family-felt burden of care average was 23.39 ( $\mathrm{SD}=7.792$ ). The family also experienced stigma from the environment, which averaged 25.09 $(\mathrm{SD}=6.358)$. The family receiving social support had an average of $31.10(S D=5.721)$. Schizophrenia patients had a level of severity of 28.11 (SD 6.954). The overall family experiencing stress had an average of $27.08(\mathrm{SD}=10.524)$

\section{Variables' correlation}

Pearson's correlation was computed between the family's stress and all of the research variables (table $2)$. The result of testing on the nine research variables showed that there was a strong relationship between burden of care $(r=0.804 ; \mathrm{p}=$ $0.00)$ and stigma $(r=0.677 ; p=0.00)$ on family stress. Subsequently, there was a weak correlation between the patient's duration of illness $(r=0.193, p$ $=0.024)$, the patient's frequency of relapse $(\mathrm{r}=$ $0.392, p=0.00)$ and the level of severity $(r=0.267, p$ $=0.002$ ) with family stress. The variables of economic status, family structure, knowledge and social support are not related to family stress during the care of patients with schizophrenia.

\section{Predictors of family stress}

As shown in Table 4, the higher the burden of care $(p=0.000$; Beta $=0.619)$, the more frequent the patient's frequency of relapse $(\mathrm{p}=0.005$; Beta $=$ $0.145)$, the higher the perceived family stigma ( $p=$ 0.000 ; Beta $=0.194$ ) and the lower functioning of the family structure $(\mathrm{p}=0.029 ;$ Beta $=-0.106)$. The aforementioned will increase stress in the family. All of the independent variables may explain the variation of family stress as $69.4 \%$ (R2=0.694). The variable that has the greatest role as a predictor of family stress is the burden of care (Beta $=0.619$ ).
Table 1. Characteristics of the respondents

\begin{tabular}{|c|c|c|}
\hline Variable & Frequency & Percentage \\
\hline \multicolumn{3}{|l|}{ Age (years) } \\
\hline $26-35$ years old & 19 & 13,9 \\
\hline $36-45$ years old & 20 & 14,6 \\
\hline 46-55 years old & 34 & 24,8 \\
\hline $56-65$ years old & 43 & 31,4 \\
\hline$>65$ years old & 21 & 15,3 \\
\hline \multicolumn{3}{|l|}{$\begin{array}{l}\text { Family's } \\
\text { structure }\end{array}$} \\
\hline Father & 11 & 8.0 \\
\hline Mother & 41 & 29.9 \\
\hline Spouse & 13 & 9.5 \\
\hline Child & 18 & 13.1 \\
\hline Siblings & 30 & 21.9 \\
\hline Relatives & 24 & 17.5 \\
\hline \multicolumn{3}{|l|}{$\begin{array}{l}\text { Family monthly } \\
\text { income }\end{array}$} \\
\hline$<3.500 .000$ IDR & 54 & 39.4 \\
\hline $\begin{array}{l}3.500 .000- \\
4.000 .000 \mathrm{IDR}\end{array}$ & 20 & 14.6 \\
\hline $\begin{array}{l}>\quad 4.000 .000 \\
\text { IDR }\end{array}$ & 63 & 46.0 \\
\hline \multicolumn{3}{|l|}{$\begin{array}{l}\text { Patient's } \\
\text { duration of } \\
\text { illness (years) }\end{array}$} \\
\hline 3 years & 16 & 11.7 \\
\hline$>3-5$ years & 18 & 13.1 \\
\hline$>5-10$ years & 31 & 22.6 \\
\hline$>10$ years & 72 & 52.6 \\
\hline \multicolumn{3}{|l|}{$\begin{array}{l}\text { Patient's } \\
\text { frequency of } \\
\text { relapse (times) }\end{array}$} \\
\hline $1-3 x$ & 63 & 46.0 \\
\hline$>3-5 X$ & 41 & 29.9 \\
\hline$>5 X$ & 33 & 24.1 \\
\hline
\end{tabular}

Table 2. Variables' description

\begin{tabular}{llcc}
\hline \multicolumn{2}{c}{ Variable } & Mean & SD \\
\hline Dependent & Knowledge & 37.93 & 3.843 \\
& Burden Care & 23.39 & 7.792 \\
& Stigma & 25.09 & 6.358 \\
& Social Support & 31.10 & 5.721 \\
& Level of & 28.11 & 6.954 \\
\hline severity & & \\
\hline Independent & Family Stress & 27,08 & 10,524 \\
\hline
\end{tabular}

\section{DISCUSSION}

Stress experienced by the family in assisting and treating patients with schizophrenia can be predicted using the variables burden of care, stigma from the environment, the patient's frequency of relapse and the functioning within the family structure. The results of this study are in line with family stress according to Hill (Rice, 1987), which mentions that family stress is caused by the interaction between stressors, family perception, and the resources owned by the family. The patient's frequency of relapse and the stigma from the environment is a stressor for the family. Stressors cause a negative perception for the families in the form of care burden. A lack of adequate functioning in the structure of the family means that the family cannot utilise the resources they own, so then the 
Table 3 Inter-correlation of the variables

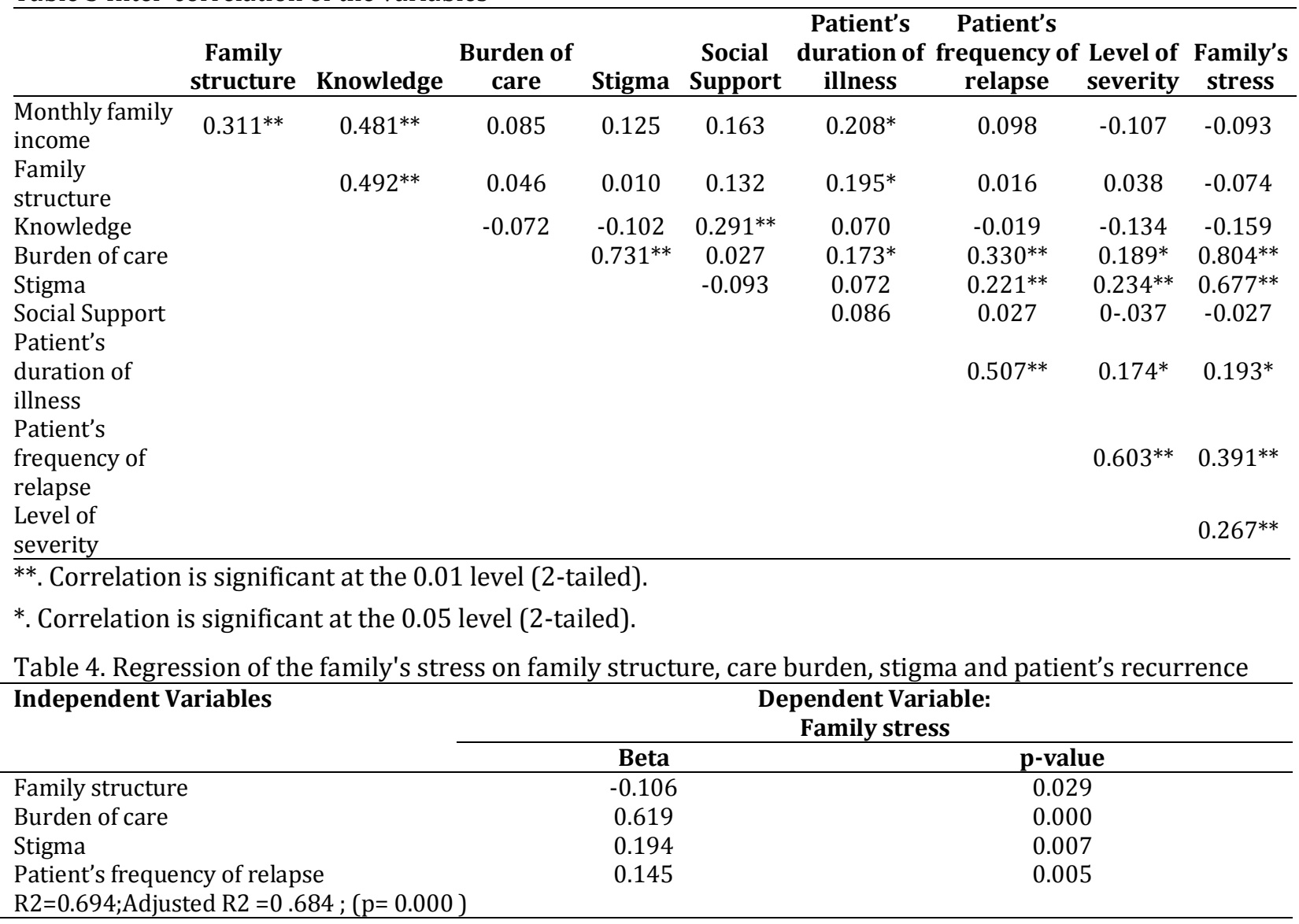

families experience stress when caring for patients with schizophrenia.

The stressors perceived by the family comes from within the family, namely the patient's frequency of relapse. The other stressors come from outside the family, including stigma. The findings of the study showed that out of all of the family members with schizophrenia, $46 \%$ experienced a relapse at least one to three times and the others, more than three times. If repeated relapse continues in patients with schizophrenia, it can have negative consequences for the caregivers (Rexha, Jose, Golay, \& Favrod, 2006). Recurrent schizophrenic patients exhibit uncontrollable behavior, such as being angry without cause, and suspicious excessive and unnatural behavior. The behavior is often exhibited not only at home, but also within the environment, which causes unrest in the community. An unpleasant response from the environment related to the patient's behavior is the stigma towards patients with schizophrenia and their families (Ariananda, 2015).

Stigma becomes a stressor for the families. Stigma is the assessment of a situation or object that is considered to be a bad thing, so their value is lower than that of a normal person. This assumption causes the family to experience discrimination and thus to lose the opportunity to engage in activities that are important in life. Stigma keeps the family impeded from the activities of daily life (Goffman, 1963 in Heatherton, 2003). The dominant stigma felt by families in this research study were discrimination and separation. The local community treats the family differently, with them being disallowed from participating in community activities involving all of the family members. Community concerns about the uncontrollable behavior of schizophrenia patients cause people to distance themselves from the patients and their families during joint activities. Neighbours who live near the family also rarely visit and avoid communicating with the patients. The results of this study are in accordance with the research of Ariananda (2015), which conveyed that the community avoids interactions involving the presence of patients and their families. Stigma causes the family to have negative perceptions, affects their emotions and causes stress (Raguram, Raghu, Vounatsu, \& Weiss, 2004; Singh, Matto, \& Grover, 2016). The high amount of stigma and the patient's frequency of relapse are stressors for the family, and affect the family's perspective of caring for schizophrenic patients at home.

The stress experienced by the family is influenced by the family's perception of the perceived stressors. The results showed that the families, in treating patients with schizophrenia, felt various forms of care burden. The perceived burden is the result of the perceptions regarding the presence of the schizophrenia patients and high stigma from the community. Treatment burden occurs as a result of the family interaction process with the sick family member in order to provide treatment. The burden 
felt is both subjective and objective (Chou, Fu, \& Lin, 2011). The treatment and care of schizophrenic patients takes a long time. The family, as the closest environment, should be able to accept the fact that sick family members should be helped to achieve better conditions for the patient. In line with the opinion of Chou (2011), this explains that the caregiver's perception of an objective burden is influenced by a number of care needs that must be met by the caregiver. The state of the schizophrenia patient is less independent and has many needs that must be fulfilled, both in relation to the needs of treatment and daily needs. This situation requires the family to provide time, energy, thought and funds. This situation creates an inconvenience for other family members. Families limit the time they have to work and interact with the social environment because they have to treat the patients with schizophrenia. Several studies have concluded that the suffering experienced by schizophrenia patients also interferes with the caregiver's comfort because they feel burdened by the regular and continuous care (Fitrikasari, Kadarman, \& Woroasih, 2012; Maldonado, Urizar, \& Kavanagh, 2005; Ochoa et al., 2008). The prolonged course of the disease, uncertain patient behaviour and family incompetence to care for the disease causes discomfort and affect the family's perspective. This study proves that the burden of patient care in relation to schizophrenia one of the predictors of family stress. The burden felt by the family is perceived negatively by the family as it is an uncomfortable situation and poses a threat to the stability of family life. Negative perceptions that continue to grow and that are not managed properly will cause the family to fall into a stressful situation.

The process of stress in the family is also influenced by the resources owned by the family. The results showed that one family resource, namely the family structure, has a role in reducing family stress. The family structure is the strength that is owned by the family to arrange their values, communication patterns and family role as a lifestyle so then the family is able to perform its function properly (Friedman, 2003). The dominant family structure in this study was the role of the mother as the primary caregiver of the schizophrenia patients (29.9\%), followed by sibling and child. The situation is influenced by the cultural structure of Indonesia that still holds true to strong family ties, so if there is one family member who is sick, then the nuclear family will take on the caregiver role to provide care. Parents or children as part of the nuclear family is a family structure that plays an important role in providing long-term care to family members who experience chronic disease, such as mental disorders (Karp, 2001; Sapin, Widmer, \& Iglesias, 2016).

This situation is also in line with the research conducted in India, in that the core family in Asian families is strong enough that the family members consider caregiving as their moral obligation (Kate, Grover, Kulhara, \& Nehra, 2012). Families have a tendency to regulate their family structure when they know that one member of their family is experiencing schizophrenia. Mothers who act as the household manager will have a greater parenting role compared to the fathers, who have to work for a living. Similarly, siblings, only when the family has no parents, become the managers of the household and will therefore be selected as the primary caregivers for the familial schizophrenia patient. Effective role sharing will help the families accept reality more quickly so as to reduce the stress experienced. An important role in the family when caring for a sick family member involves the process of making the decision to seek immediate solutions and to begin the treatment process (Carpentier, 2013; Sapin et al., 2016). However, it is possible for there to be a conflict within the family due to an imbalance of role sharing within the family structure (Sapin et al., 2016; Widmer, 2010). The primary caregiver feels a heavier burden than the other family members who do not accompany the patient. Therefore, the family needs resources from outside of the family, such as social support from the environment. The social support received by families is a positive indicator of the family burden during the care of patients with schizophrenia (Chow, 2013 in Poegoeh \& Hamidah, 2016). The results of this study found that social support is not a predictor of family stress. According to Widmer (2010) and Sapin (2013), social support sourced from the environment (community and extended family) is very effective and necessary for the families caring for schizophrenia patients early in their treatment that does not impact on long-term care. Sadath (2017) explained that social support is not one of the factors that determines the emotional expression of families that have been predicted to experience family stress. This is because families have limited access to social support while caring for patients. Families who treat patients with schizophrenia tend to limit themselves in order to take advantage of the social support provided by the surrounding environment. The family assumes that the existence of the patient is a disgrace to the family (Hawari, 2009), so the family feels that they do not want to tell anyone about the illness. In addition to these assumptions, families who have tried to ask for support from neighbours and their extended families, do not feel the benefit, so the family feels isolated and discriminated against by the environment. As a result of resource utilisation in reducing stress, families choose to optimise the family structure when caring for schizophrenic patients and do not use social support from the environment.

\section{Research implications}

The research findings reinforce the ABCX theory according to Hill (Rice, 1987). The frequency of patient relapse and the stigma experienced by the family were stressors. The presence of stressors is interpreted by the family as a burden of care. 
Families try to optimise the family's strength, called family structure, as a resource for managing stressors, but if the family may think that if the stressors are threatening to the family stability, then this may result in a family burden. This situation brings families into stressful situations. Nurses, as health professionals who are willing to interact directly with the family, can develop family nursing interventions, especially in relation to stress management. Nurses can do stimulations that helps the families to modify the family perceptions of the stressor, which was originally considered to be a challenge in treating patients with schizophrenia.

The findings of the study have proven that the patient's frequency of relapse, stigma, the burden of care, and family structure can predict the stress experienced by the families during the care of schizophrenic patients. Based on the theory of family centre and nursing (Friedman, 2003), the results of this study have implications for nurses. This is as they seek to conduct a family assessment which pays attention to the patient factors, especially the frequency of patient relapse. The nurses also must be attentive to the family factors, namely family structure and the family perceptions related to burden and stigma. The nurses should be able to identify the patient's relapse frequency, family structure, the burden of care and stigma as the family's stress indicators, so they can help the family to manage stress.

\section{Research limitation}

This research has several limitations. The sample of the study was obtained from the families who accompany the patients to the outpatient unit. The perception of stress experienced by the family was strongly influenced by the situation and the acute condition of the patient at that time. This caused less access to the social support that was used. Another limitation is that the results of this study has a limited potential for generalisation, especially for the family's stress when the patients are hospitalised.

\section{CONCLUSION}

The stress experienced by the family when taking care of patients with schizophrenia is determined by the family's perception of the stressor. Family stress can be predicted based on the patient frequency of relapse, the stigma felt by the family, the large burden of care and the family structure, which may not function optimally. Nurses as health care providers can develop an assessment format that focuses on the family stress predictors, helping them to develop family stress management that focuses on establishing positive perceptions and enhancing the functioning of the family structures, enabling them to manage the burden of care and stigma experienced.

\section{REFERENCES}

Akbar, M. (2008). Schizophrenia: Psikosis (Mental
Illnes). Jakarta: Balai Pustaka.

Amaresha, A. C., \& Venkatasubramanian, G. (2012). Expressed emotion in schizophrenia: An overview. Indian J Psychol Med, 34(1), 12-20. http://doi.org/10.4103/0253-7176.96149

Ariananda, R. E. (2015). Public stigma toward to schizophrenia patients. Skripsi. Universitas Negeri Semarang, Semarang.

Biegel. (1995). Innovations in Practice and Service Across The Lifespan. New York: Oxford University.

Brillianita, K. A., \& Munawir, A. (2014). Hubungan antara gejala positif dan negatif skizofrenia dengan tingkat depresi pada caregiver pasien skizofrenia. Artikel Ilmiah Hasil Penelitian 2014. Jember. Retrieved from http://dspace.unej.ac.id/bitstream/handle/1234 56789/67526

Carpentier, N. (2013). Entry into a care trajectory: individualization process, network, and emerging project. Sage Open, 1-9. http://doi.org/http://dx.doi.org/10.1177/21582 44013494215

Chou, Y.-C., Fu, L.-Y., \& Lin, L.-C. (2011). Predictors of subjective and objective caregiving burden in older female caregivers of adults with intellectual disabilities. International Psychogeriatrics, 23(4), 562-572. http://doi.org/10.1017/S1041610210001225

Darwin, P., Hadisukanto, G., \& Elvira, S. D. (2013). Burden of care and emotional expression of nurses work with schizophrenia patient in mental hospital. Journal of Indonesian Medical Association, 63(2), 46-51.

Djatmiko. (2007). Berbagai Indikator Taraf Kesehatan Jiwa Masyarakat. Retrieved January 5, 2016, from http://pdskjijaya.com

El Tantawy, A. M. A., Raya, Y. M., \& Zaki, A. M. K. (2010). Depressive disorders among caregivers of schizophrenic patients in relation to burden of care and perceived stigma. Current Psychiatry, $17(3)$.

Ennis, E., \& Bunting, B. P. (2013). Family burden , family health and personal mental health. $B M C$ Public Health, 13(1), 1. http://doi.org/10.1186/1471-2458-13-255

Fadli, S. M., \& Mitra. (2013). Knowledge and emotional expression of family and relaps frequency of schizophrenic patients. Jurnal Kesehatan Masyarakat Nasional, 7(10), 466-470.

Fitrikasari, A., Kadarman, A., \& Woroasih, S. (2012). Gambaran beban caregiver penderita skizofrenia di Poliklinik Rawat Jalan RSJ Amino Gondohutomo Semarang. Medica Hospitalia, 1(2), 118-122.

Friedman, M. M. (2003). Keperawatan Keluarga: Teori dan Praktek. Jakarta: EGC.

Hadryś, T., Adamowski, T., \& Kiejna, A. (2011). Mental disorder in Polish families: is diagnosis A predictor of caregiver's burden? Social Psychiatry and Psychiatric Epidemiology, 46(5), 363-372. http://doi.org/10.1007/s00127-010-0200-8

Hawari, D. (2009). Pendekatan Holistik pada 
Gangguan Jiwa: Skizofrenia. Jakarta: FKUI.

Heatherton, T. F. (2003). The Social Psychology of Stigma. New York: The Guilford Press.

Karp, D. (2001). The Burden of Sympathy: How Families Cope with Mental Illness. New York: Oxford University Press.

Kate, N., Grover, S., Kulhara, P., \& Nehra, R. (2012). Relationship of quality of life with coping and burden in primary caregivers of patients with schizophrenia. The International Journal of Social Psychiatry, 10(2), 1-10. http://doi.org/10.1177/0020764012467598

Kellner, R., \& Sheffield, B. (1973). A self-rating scale of distress. Psychological Medicine, 3, 88-100.

Kemenkes RI. (2013). Riset Kesehatan Dasar. Badan Penelitian dan Pengembangan Kemenkes RI. Jakarta. Indonesia.

Levine, J., \& Levine, I. (2009). Schizophrenia for Dummies. New Jersey: Jhon Whily Publishing Inc.

Link, B. G., \& Phelan, J. C. (2001). Conceptualizing stigma. Annual Review of Sociology, 27, 363-385.

Maldonado, J., Urizar, A., \& Kavanagh, D. (2005). Burden of care and general health in families of patients with schizophrenia. Social Psychiatry and Psychiatric Epidemiology, 40, 899-904.

McCubbin, H. I., Paterson, J., \& Glynn, T. (1987). Family Assessment: Resiliency, Coping and Adaptation: Inventories of Research and Practice. Madison, Wisconsin: University of Wisconsin Publisher.

McCubbin, H., \& Thompson, A. (1991). Family Assessment Inventories for Research and Practice. Madison: University of Wisconsin.

Ochoa, S., Vilaplana, M., Haro, J., Villalta-Gil, V., Martinez, F., Negredo, M., ... Autonell, J. (2008). Do needs, symptoms or disability of outpatiens with schizophrenia influence family burden? Social Psychiatry and Psychiatric Epidemiology, 43(3), 612-618.

Overall, J. E., \& Gorham, D. R. (1988). The Brief Psychiatric Rating Scale (BPRS): Recent Developments in Ascertainment and Scaling. Psychopharmacology Bulletin, 24, 97-99.

Pharoah, F., Mari, J., Rathbone, J., \& Wong, W. (2010). Family Intervention for Schizophrenia (Review). Wiley publishers.

Poegoeh, D. ., \& Hamidah. (2016). Peran Dukungan Sosial dan Regulasi Emosi Terhadap Resiliensi Keluarga Penderita Skizofrenia. Insan, 1(1).

Raguram, R., Raghu, T., Vounatsu, P., \& Weiss, M.
(2004). Schizophrenia and the cultural epidemiology of stigma in Bangalore, India. Journal Nerv. Mental Disorder, 192, 734-744.

Rexha, P. ., Jose, A., Golay, P., \& Favrod, J. (2006). Perceptions of schizophrenia and coping styles in caregivers: comparison between India and Switzerland. Journal of Psychiatric and Mental Health Nursing, 23, 585-594.

Rice, V. H. (1987). Handbook of Stress, Coping and Health: Implications of Nursing Research, Theory and Practice. Thaousand Oaks: Sage Publications.

Sadath, A., Muralidhar, D., Varambally, S., Gangadhar, B., \& Jose. JP. (2017). Do stress and suppoer matter of caring? The role of perceived stres and social support on emotional expression of carers of person with first episode of psychosis. Asian Journal of Psychiatry, 25, 163-168.

Sapin, M. (2013). Configurations de proches et adaptation dans le parcourse de vie d'individus en situation de vulnerabilite. University of Laussane.

Sapin, M., Widmer, E., \& Iglesias, K. (2016). From support to overload: patterns of positive and negative family relationships of adults with mental illness over tima. Social Networks, 47, 5972.

http://doi.org/http://dx.doi.org/10.1016/j.socne t.2016.04.002

Singh, A., Matto, S., \& Grover, S. (2016). Stigma and its correlates among caregivers of schizofrenia: A study from North India. Psychiatry Research, 241, 302-308.

Stuart, G., \& Sundeen, S. (2012). Principles and Practice of Psychiatric Nursing. St. Louis: Mosby Year Book.

Stuart, G. W., \& Sundeen. (2005). Buku Saku Keperawatan Jiwa (3rd ed.). Jakarta: EGC.

Suhita, B. M., Siyoto, S., Wardhani, R., Puspitasari, Y., \& Wahyuni, C. U. (2015). The Identification of families stress level with adversity quotient in caring schizophrenia family members in Kediri city. Journal of Appied Environmrnt and Biological Science, 5(12), 106-113.

Thornton, M., \& Travis, S. (2003). Analysis of the reliability of the modified cargivere strain index. The Journals of Gerontology, 58(2), S127-S132.

Widmer, E. (2010). Family Configuration: A Structral Approach to Family Diversity. London: Ashgate Publishing.

World Health Organization. (2008). Investing in mental health. Geneva. 